\title{
DESIGN AND DEVELOPMENT OF A SMALL-SCALE BIOMASS DOWNDRAFT GASIFIER
}

\author{
P. E. Akhator ${ }^{1, *}$, A. I. Obanor ${ }^{2}$ and E. G. Sadjere ${ }^{3}$ \\ 1, 2, 3, Department of MeChanical Engineering, University of Benin, Benin City, Edo State, NigeRIA. \\ E-mail addresses: ${ }^{1}$ peter.akhator@uniben.edu, ${ }^{2}$ aiobanor@yahoo.com, 3 godwin.sadjere@uniben.edu
}

\begin{abstract}
This study focused on the design and testing of a downdraft gasifier. The gasifier design was based on a combination of the Imbert and stratified models with some modifications. Sizing of the gasifier was done using empirical relations and some experimental data relating to specific gas generation rate, biomass flow rate, throat diameter and reduction zone diameter etc. The thermal capacity of the gasifier was set at $5 \mathrm{~kW}$. A cyclone separator, an air-cooling unit and a filter unit (containing wood shavings) were coupled to the gasifier's reactor to purify the produced syngas. The gasifier system was tested in a forced draught mode using air as the gasifying medium. The feedstock conversion rate of the gasifier was $1.25 \mathrm{~kg} / \mathrm{hr}$ for wood chunks $(10-70 \mathrm{~mm})$ and $2.1 \mathrm{~kg} / \mathrm{hr}$ for wood shavings (2-5mm). The syngas produced for both types of wood residues burnt with stable blue flames, indicating minimal tar percentage in the syngas. This signifies that the produced syngas can be safely utilized not only for cooking but also in internal combustion engines to generate electricity.
\end{abstract}

Keywords: Bioenergy, Biomass, Downdraft gasifier, Gasification, Renewable energy, Synthesis gas, Wood waste.

\section{INTRODCUTION}

Biomass is one of the important sources of renewable energy. By 2050 , biomass could provide nearly $38 \%$ of the world's direct fuel use and $17 \%$ of the world's electricity [1]. Biomass utilization for energy generation does not make any net addition to the earth's carbon dioxide levels. When it burns, it releases the carbon dioxide that the plants had absorbed from the atmosphere recently. One of the attractive technologies for converting biomass to energy is gasification and the equipment used in gasification process is referred to as gasifier.

Gasification is a thermo-chemical process whereby carbonaceous materials, such as biomass, are converted via incomplete combustion at high temperatures into a combustible gas. The combustible gas, known as synthesis gas (syngas), is a mixture of carbon monoxide, hydrogen, methane, carbondioxide, nitrogen and water vapour. The produced gas is more versatile in its use than the original solid biomass. It can be burnt to produce process heat and steam or used in gas turbines and internal combustion engines to produce electricity [2].Compared to other gasification technologies, the downdraft gasifier is the most suitable option for decentralized heat and power generation because the syngas obtained from it contains very low amount of tar and particulates [3]. This justifies the choice of this type of gasifier for the present study. The performance of the gasification process depends mainly on the types of feedstock and its characteristics such as moisture content, composition, equivalence ratio and the gasifier design [4]. Inappropriate selection of these parameters may lead to excessive presence of tar and soot in the produced gas. These contaminants in the syngas may disturb the continuous and smooth operation of downstream gas engines [5]. For applications oriented towards heat and power generation, cleaning of the syngas is essential to avoid corrosion and clogging in the engine pipes.

Many researchers have attempted to enhance the gasification efficiency by implementing design 
modifications to downdraft gasifier. Virmmond, et. al [6] studied the effect of size and shape of feedstock on efficiency in different types of reactors. They concluded that finer and low density feedstock will have bridging problems especially, in the throated gasifiers. Mukunda [7] achieved higher efficiency by allowing air distribution, increasing insulation and recirculating gas within the reactor thereby utilizing the sensible heat in the gas to dry the biomass. Bario, et. al [8] modified air distribution system and injected air at the centre of the reactor cross section so that air is distributed uniformly to all sides of the reactor. They also used a perforated grate with manual actuation to clear the ash contents continuously and to ensure smoother bed movement. Dasappa, et. al [9] used multilevel air injection system to increase the residence time to promote tar cracking and gas yield. Liinanki, et. al [10] used a double conical hopper and rotating grate. Double conical hopper reduced the bridging problem in the pyrolysis zone while rotating grate reduced ash agglomeration problem. Altafini, et. al [11] used recirculation of produced gas to increase the reactor temperature and thereby reducing tar formation and increasing efficiency.

The development of biomass gasification technology in Sub-Sahara Africa (SSA) requires on one hand a full knowledge and control of the techniques of gasifiers' design and on the other hand an improvement of the performances of the process. A 2017 DFID [12] study on Bioenergy for Sustainable Energy Access in Africa (BSEAA) revealed that although biomass gasification have huge potential for power generation in SSA, such projects have been hampered by several challenges. These challenges include mainly high tar content in the syngas, stringent feedstock requirements as well as lack of local technical and engineering capacity to operate and maintain the gasifier systems (which were all imported). For example, a gasifier in Nigeria from the Indian Institute of Science only worked intermittently and required an Indian engineer to come in for essential repairs. Much efforts are needed in this field in Sub-Sahara Africa not only to increase electricity availability but also to effectively manage biomass and urban solid wastes that are causing menace to humans and environment in the region.

Several researchers in SSA have conducted experiments on biomass gasification using various biomass feedstock for synthesis gas production. Gado, et. al [13] designed and tested a downdraft gasifier using rice husk, balanitesaegyptiaca hulls and charcoal as feedstock. Gasification tests revealed biomass consumption rate of $4.8 \mathrm{~g} / \mathrm{hr}, 7.2 \mathrm{~kg} / \mathrm{hr}$ and $2.2 \mathrm{~kg} / \mathrm{hr}$ for rice husk, hulls of balanitesaegyptiaca and charcoal respectively with corresponding gas production indicated by gas ignition at the flare tube. They however experienced biomass bridging at the throat during testing with rice husk, and hence recommended the installation of a grate agitator. Akinola and Fapetu [14] investigated the pyrolysis of wood wastes from sawmills using a fixed-bed batch reactor. They discovered that for every kilogram of wood waste pyrolysed, $39.15 \%$ char, $40.26 \%$ bio-oil and $20.59 \%$ were obtained. Ojolo and Orisaleye [15] developed twin outlets system for effective ash discharge and tested the gasifier in natural and forced draught conditions. They found that forced draft system gives better efficiency with minimum char formation. Mobi, et al [16] developed a biomass gasifier stove using dry cow dung as feedstock. Experimental tests revealed that the gas produced by the stove was able to boil ten litres of water within 10 minutes.

However, none of these reports indicated the provision of syngas cleaning facility beyond cyclone that was available only in the design by [13]. For optimal and safe utilization of syngas in downstream equipment, gas cleaning is necessary. The present study is an attempt to design, develop and test a small downdraft gasifier equipped with syngas cleaning facilities at University of Benin, Benin City, Nigeria.

\section{MATERIALS AND METHODS}

\subsection{Materials}

The biomass used are wood wastes (shavings and chunks) generated in the woodwork section of the Faculty of Engineering Workshop, University of Benin, Benin City, Edo State, Nigeria. The wood waste is a mixture of the several wood species that are used to make furniture in the workshop. These mixed wood wastes were used for this study. The average sizes of the wood shavings were $2-5 \mathrm{~mm}$ and wood chunks were $10-70 \mathrm{~mm}$. Figure 1 shows the wood waste used for the study.

The materials used for the fabrication of the gasifier system components were locally sourced and available. The materials included metal sheets, metal drums, galvanized iron pipes and bars, flanges, straight fittings, and ball valves. Non-metal items included sealing materials/gasket, jam bottles, and insulating tape. The electrical equipment included a 12-volt, 3000-rpm blower, and 12volts battery. 


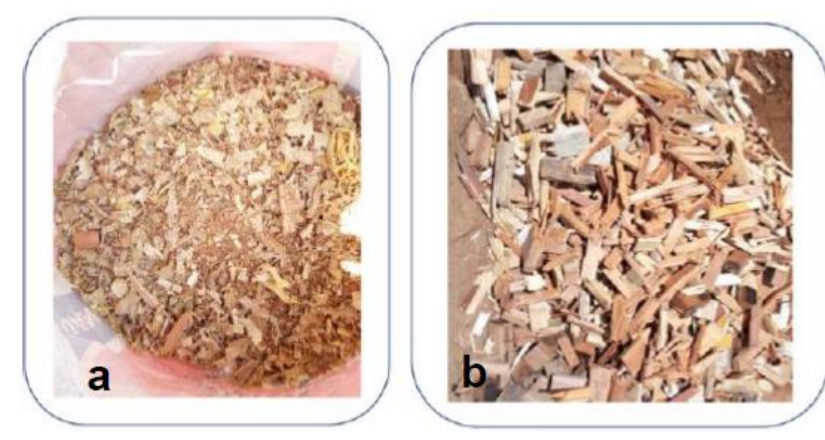

Figure 1: (a) Wood shavings and (b) wood chunks tested in the gasifier.

\subsection{Methods}

The first step was to find a feasible design, which could be taken as the basis for the gasifier construction. The design is a modified combination of both the Imbert (throated or closed top gasifier) and stratified (throatlessor open core) downdraft gasifier designs. This is to take advantage of the merits of both designs, especially the ease of biomass feeding into the gasifier via the open top and the tar cracking effect of the throat. A grate shaker was included to address the problem of feedstock bridging at the throat. It was also decided that, at this stage, syngas would be burnt in a simple burner rather than feed it to an internal combustion engine. After a few technical considerations, $5 \mathrm{~kW}$ capacity was decided as the designed output for the downdraft gasifier.

\subsubsection{Design of the Gasifier}

The design is done partly through computations, partly using empirical relations and using some experimental data. The gasifier reactor was sized as follows:

1) The capacity(the thermal power output) of the gasifier and the gasifying agent was set;

2) The type of biomass, the syngas lower heating value (LHV) and the efficiency of the gasifier was chosen.

3) The appropriate parameter for sizing the gasifier using mathematical formulas and experimental data were determined.

The appropriate parameters for the design of downdraft gasifier are the throat diameter, the type of biomass, equivalence ratio, the air tuyeres diameter, specific gasification rate, relative reactor tube capacity, diameter of the reactor hopper, height of the reactor hopper, height of the throat, and height of the reduction zone.

\subsubsection{Determination of appropriate parameters}

The use of air as gasifying agent is inexpensive and the produced gas, though has a low LHV (between 3 and $5 \mathrm{MJ} / \mathrm{Nm}^{3}$ ) [17], is still sufficient for electrical and thermal applications. Thus, air was chosen as the gasifying agent for this study. Henriksen, et al [18] and Mukunda [7] reported gasifier efficiencies ranging from 60 to $80 \%$, therefore, a gasifier efficiency of $60 \%$ was considered for this study. Equivalence ratio is defined as the ratio of actual air amount to stoichiometric air amount. A value of 0.4 is a theoretical optimum and is the value used for this study.

Specific gasification rate (SGR) is the volume flow rate of gas per unit area based on throat diameter, the gas volume being measured at standard conditions. The recommended SGR value falls in the range of 1920$2640 \mathrm{~m}^{3} / \mathrm{m}^{2} \mathrm{hr}$ [19]. Relative reactor tube capacity (RTC) is the mass flow rate of biomass per unit area based on the diameter of the tube. The recommended RTC value ranges from $250-300 \mathrm{~kg} / \mathrm{m}^{2} \mathrm{hr}$ [19]. Table 1 presents the assumptions and initial design conditions used for this study.

Table 1: Assumptions and initial design conditions

\begin{tabular}{ll}
\hline Gasifier Type & $\begin{array}{l}\text { Downdraft (throated } \\
\text { with open top) }\end{array}$ \\
\hline Biomass type & Wood waste \\
Calorific value (CV) of & $\begin{array}{l}19.85 \mathrm{MJ} / \mathrm{kg} \\
\text { (experimentally } \\
\text { determined) }\end{array}$ \\
feedstock & $225 \mathrm{~kg} / \mathrm{m}^{3}$ \\
Density of feedstock & $60 \%$ \\
Gasification efficiency ( $\mathrm{\eta})$ & $2000 \mathrm{~m}^{3} / \mathrm{m}^{2} \mathrm{hr}$ \\
Specific Gasification rate & $250 \mathrm{~kg} / \mathrm{m}^{2} \mathrm{hr}$ \\
Relative Tube capacity & 0.4 \\
Equivalence Ratio (ER) & $5 \mathrm{~kW}$ \\
Thermal Power output (P) & \\
Lower heating value (LHV) & $4 \mathrm{MJ} / \mathrm{Nm}^{3}$ \\
of syngas & \\
\hline
\end{tabular}

Sivakumar, et al [20] discovered from their model that throat angles of about $45^{\circ}$ increases the cumulative conversion efficiency while larger angles of about $90^{\circ}$ decreases the cumulative conversion efficiency because of a decreased temperature for larger throat angles due to the divergent effect and the reaction rate. Venselaar [19] also recommended, after comparison of the design characteristics of a number of gasifiers, that the throat inclination should be around $45^{\circ}$ to $60^{\circ}$. A throat angle of $60^{\circ}$ was used for the design. Sivakumar, et al [21] suggested optimum 
results are obtained when the angle of inclination of the air nozzles is between $10^{\circ}$ and $25^{\circ}$. An inclination of $\mathbf{1 5}^{\circ}$ was used for this study.

\section{a. Syngas Generation Rate (SG)}

For a thermal power output of $5 \mathrm{~kW}, \mathrm{SG}$ is obtained from

$$
\mathrm{SG}=\frac{\mathrm{P}}{\mathrm{LHV}}=4.5 \mathrm{~m}^{3} / \mathrm{hr}
$$

\section{b. Fuel Consumption Rate (FCR)}

$$
\mathrm{FCR}=\frac{\mathrm{P}}{\mathrm{CV} \times \eta}=1.511 \mathrm{~kg} / \mathrm{hr}
$$

\section{Air flow Rate (AFR)}

To determine the airflow rate, ultimate analysis of the mixed wood waste is required. Table 2 presents the ultimate analysis of the mixed wood waste as determined in this study.

Table 2: Ultimate analysis of mixed wood wastes

\begin{tabular}{lc}
\hline Constituents & Percentage by weight \\
\hline Carbon & 57.54 \\
Hydrogen & 5.21 \\
Oxygen & 37.10 \\
Nitrogen & 0.11 \\
Sulphur & 0.04 \\
\hline
\end{tabular}

Stoichiometric air requirement computation is shown

\begin{tabular}{|c|c|c|c|}
\hline C & + & $\mathrm{O}_{2}$ & $\mathrm{CO}_{2}$ \\
\hline 12 & & 32 & 44 \\
\hline 57.58 & & 153.547 & 211.127 (for $100 \mathrm{~kg}$ of wood chips) \\
\hline $\mathrm{H}_{2}$ & + & $0.50_{2}$ & $\rightarrow \quad \mathrm{H}_{2} \mathrm{O}$ \\
\hline 2.016 & & 16 & 18 \\
\hline 5.21 & & 41.349 & 46.518 (for $100 \mathrm{~kg}$ of wood chips) \\
\hline $\mathbf{S}$ & + & $\mathrm{O}_{2}$ & $\mathrm{SO}_{2}$ \\
\hline 32 & & 32 & 64 \\
\hline 0.04 & & 0.04 & 0.08 (for $100 \mathrm{~kg}$ of wood chips) \\
\hline
\end{tabular}
below:

Total theoretical $\mathrm{O}_{2}$ required for complete combustion of $100 \mathrm{~kg}$ of wood chips is

$$
\begin{array}{r}
{\left[\mathrm{O}_{2}\right]_{\mathrm{th}}=153.547+41.349+0.04-37.10} \\
=157.836 \mathrm{~kg} \text { per } 100 \mathrm{~kg} \text { of wood chips } \\
=1.578 \mathrm{~kg} \text { per } \mathrm{kg} \text { of wood chips. }
\end{array}
$$

Therefore, total theoretical air required for complete combustion of $1 \mathrm{~kg}$ of wood chips is

$$
\left(\mathrm{m}_{\mathrm{a}}\right)_{\text {sto }}=6.861 \mathrm{~kg}
$$

Hence, the stoichiometric air-fuel $(A / F)$ ratio is

$$
\left(\frac{\mathrm{ma}_{\mathrm{a}}}{\mathrm{mf}_{\mathrm{f}}}\right)_{\text {sto }}=6.861
$$

Actual air-fuel $(A / F)$ ratio can be obtained from

$$
\mathrm{ER}=\frac{\text { Actual } \mathrm{A} / \mathrm{F}}{\text { Stoi chiometric } \mathrm{A} / \mathrm{F}}
$$

$$
\Rightarrow \text { Actual } \mathrm{A} / \mathrm{F}=2.7444
$$

Hence, the actual mass flow of air required for the design conditions is

$\dot{\mathrm{m}}_{\mathrm{a}}=2.7444 \times 1.511=4.168 \mathrm{~kg} / \mathrm{hr}$

Low pressure air blower is used to supply air to the gasifier, for such low-pressure ratio air is treated as incompressible fluid. Considering normal temperature and pressure conditions, the volume airflow rate $\left(V_{a}\right)$ is given by

$$
\mathrm{V}_{\mathrm{a}}=\frac{\dot{\mathrm{m}}_{\mathrm{a}} \times \mathrm{R} \times \mathrm{T}}{\mathrm{P}}=3.224 \mathrm{~m}^{3} / \mathrm{hr}
$$

\section{a. Throat Design}

The gasifier's throat diameter is designed from Specific Gasification Rate (SGR) value. Hence,

$$
\mathrm{SGR}=\frac{\mathrm{SG}}{\mathrm{A}_{\mathrm{th}}}
$$

Where, Ath $=$ Area of throat, $\quad \mathrm{SG}=4.5 \mathrm{~m}^{3} / \mathrm{hr}$ and $\mathrm{SGR}=2000 \mathrm{~m}^{3} / \mathrm{m}^{2} \mathrm{hr}$

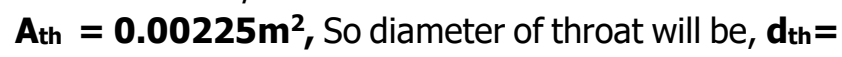
$5.4 \mathrm{~cm}$

For flow stability of biomass inside gasifier, ratio of throat height to throat diameter is taken as 1.5 [19]. $\therefore$ Height of throat $\left(h_{\text {th }}\right)=5.4 \times 1.5=\mathbf{8 . 1} \mathbf{c m}$

\section{b. Height of reduction Zone $\left(h_{r}\right)$}

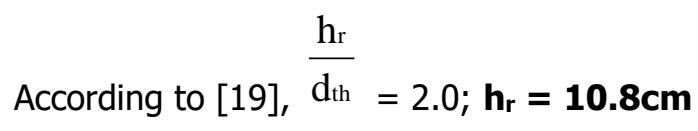

c. Diameter Reactor Hopper $\left(D_{h}\right)$

To calculate $D_{h}$, Relative Capacity of Tube (RCT) is used. RCT was taken as $250 \mathrm{~kg} / \mathrm{m}^{2} / \mathrm{hr}$

$$
\mathrm{RCT}=\frac{\mathrm{FCR}}{\mathrm{A}_{\mathrm{h}}}
$$

Where, $A_{h}=$ area of reactor hopper

$\mathrm{FCR}=$ actual mass flow rate of biomass in $\mathrm{kg} / \mathrm{hr}$

$$
\text { So, } D_{h}=8.77 \mathrm{~cm}
$$

\section{d. Height of Reactor Hopper $\left(\mathrm{H}_{\mathrm{h}}\right)$}

Assuming a value of $225 \mathrm{~kg} / \mathrm{m}^{3}$, the volume required to store $1.511 \mathrm{~kg}$ of wood chips for $1 \mathrm{hr}$ operation of gasifier $=0.0067156 \mathrm{~m}^{3}$. The height of the reactor of cylindrical cross section is obtained from

$$
\text { Height }=\frac{\text { Volume }}{\text { Cross sectional area }}=1.112 \mathrm{~m}
$$




\section{e. Diameter of tuyere $\left(D_{t}\right)$}

This is obtained from the equation 8

$$
\mathrm{D}_{\mathrm{t}}=\sqrt{\frac{4 \times \mathrm{V}_{\mathrm{a}}}{\Pi}}=3.377 \mathrm{~cm}
$$

\section{f. Diameter of Syngas outlet Nozzle ( $\left.D_{g}\right)$}

The diameter of syngas exit nozzle can be obtained from equation 11

$$
D_{\mathrm{g}}=\sqrt{\frac{4 \times \mathrm{SG}}{\Pi}}=3.99 \mathrm{~cm}
$$

Figure 2 shows the various sections of the designed gasifier.

\subsubsection{Design of Cyclone}

The maximum syngas flow rate of $5 \mathrm{~m}^{3} / \mathrm{hr}$ with a gas velocity of $15 \mathrm{~m} / \mathrm{s}$ at $300^{\circ} \mathrm{C}$ was designed to pass through the cyclone. The main dimension of geometry of the cyclone was obtained from assumptions and from the geometrical ratios provided by Simplex [22] as shown in Table 3 and Figure 3.

\subsubsection{Filter}

Filter was designed base on gas retention time in filter of 5 second. The filter height $(h 1+h 2+h 3)$ was designed to be approximately $70 \mathrm{~cm}$ than the filter diameter $\left(D_{f}\right)$ was obtained. Dimension details are shown in Table 4 and Figure 4. Filter was divided into three stages: the second stage contained wood shavings.

\subsubsection{Construction}

The Gasifier system was constructed as shown in Figure 5. The arrangement of gasifier system was gasifier reactor, cyclone, cooler, filter and gas burner.

Table 3: Dimensions of cyclone

\begin{tabular}{ll}
\hline Dimension & Value $(\mathrm{cm})$ \\
\hline Cyclone body diameter $(\mathrm{D})$ & 14 \\
Cyclone inlet diameter $\left(\mathrm{D}_{\mathrm{i}}\right)$ & 4 \\
Diameter of gas exit $\left(\mathrm{D}_{\mathrm{e}}\right)$ & 3.5 \\
Length of vortex finder $(\mathrm{S})$ & 10.5 \\
Length of body $(\mathrm{L})$ & 56 \\
Diameter of dust exit $\left(\mathrm{D}_{\mathrm{d}}\right)$ & 3.85 \\
\hline
\end{tabular}

Table 4: Dimension of filter

\begin{tabular}{cc}
\hline Dimension & Value $(\mathrm{cm})$ \\
\hline h1 & 10 \\
h2 & 50 \\
h3 & 10 \\
Df & 35 \\
\hline
\end{tabular}

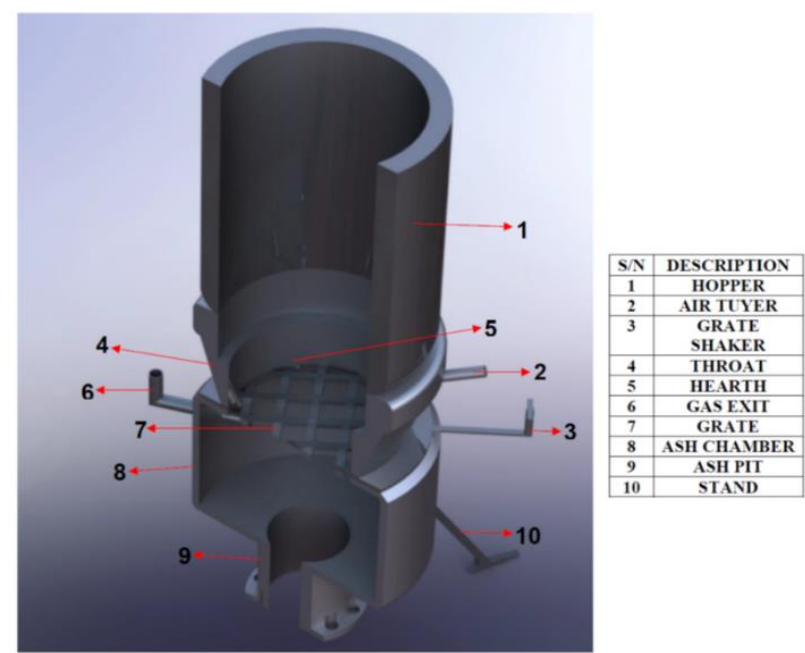

Figure 2: The cross sectional view of the designed gasifier

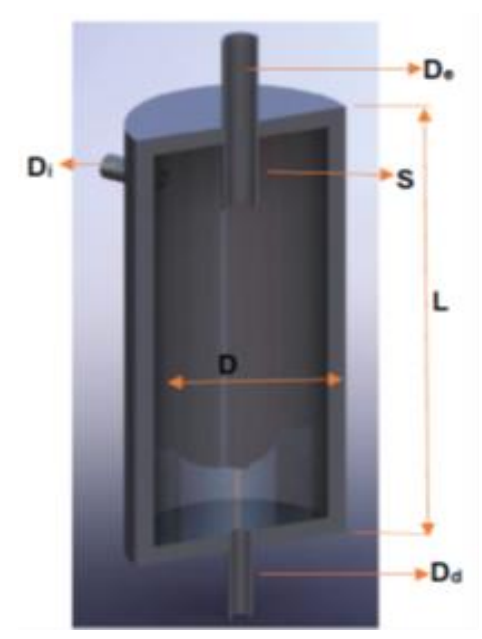

Figure 3: Cross sectional view of the cyclone

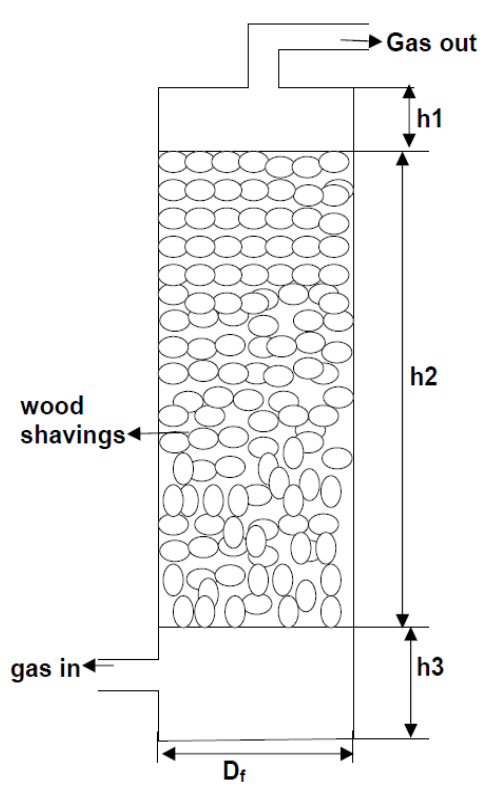

Figure 4: Schematic of filter 


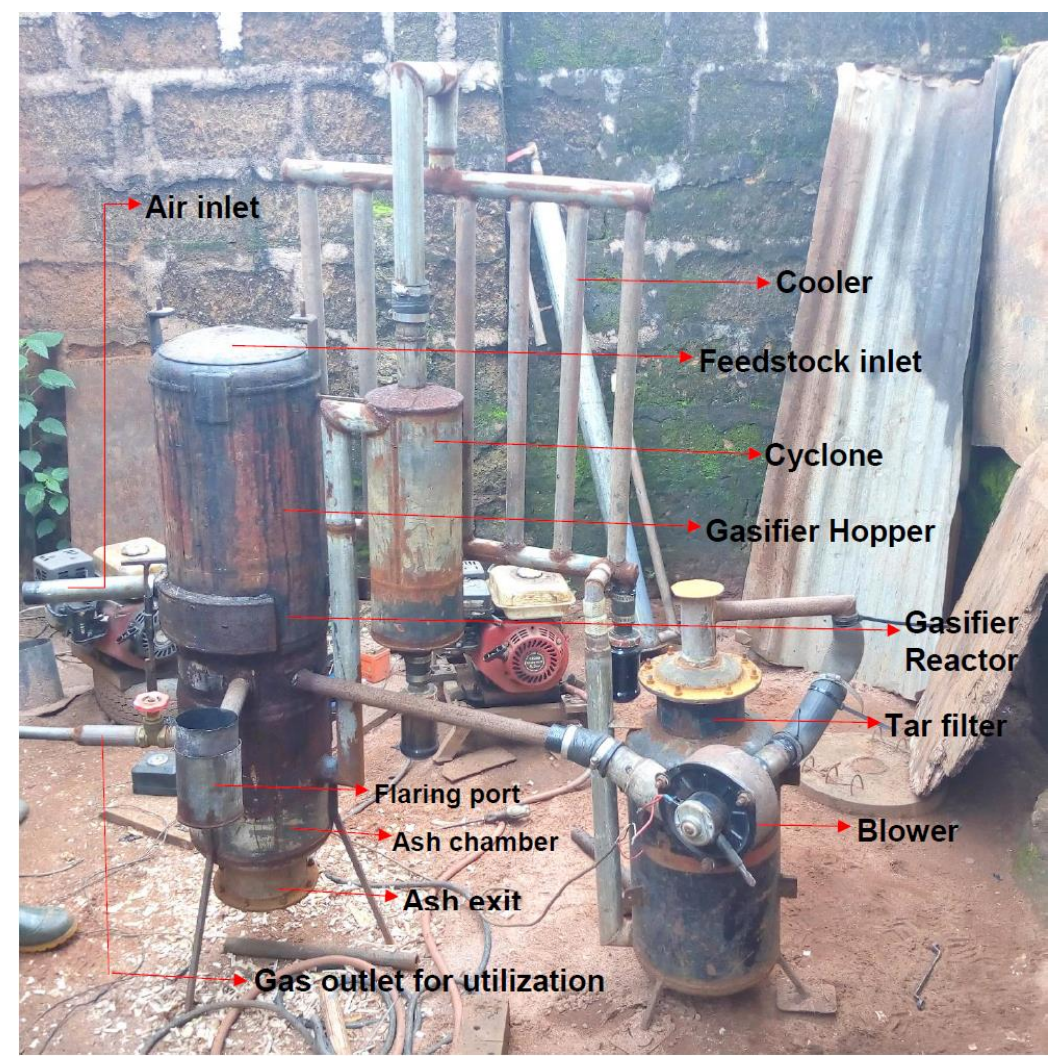

Figure 5: Constructed gasifier system

\subsubsection{Experimentation Procedure}

The performance of the fabricated gasifier was tested using wood wastes (shavings and chunks) in forced draft mode. Before starting, all the components including flange attachments and fittings of the gasifier were checked for leakage and the system was placed in an open space. The top cover of the gasifier was opened, some pieces of charcoal was placed on the grate inside the gasifier and wetted with kerosine. The charcoal was ignited with a torch and the blower was switched on to supply sufficient air to initiate and sustain combustion. After sufficient temperature was attained, the gasifier was loaded with biomass in multiples of $1 \mathrm{~kg}$ through the open top of the gasifier hopper. The syngas produced was ignited and the characteristics of the gas and flame were observed. The consumption rate of biomass was also observed. The feedstock consumption rate was estimated using equation (10) shown below this page.

\section{RESULTS AND DISCUSSION}

The gasifier was first fired using wood shavings as feedstock, then with wood chunks and performance was observed. Based on these, few modifications were made to the design. During the first run, the syngas burnt with unstable yellowish-red flame. The reasons identified were short residence time of the tarry vapours due to high gas velocity in the hot zone, wet wood chips and insufficient wood shavings in the filter. Therefore, the gas outlet pipe was replaced with a larger diameter $(4.5 \mathrm{~cm})$ pipe. Other important modifications made were in the filter by increasing the quantity and compactness of the wood shavings in it as well as modification in the burner to reduce gas velocity. Finally, a provision was made to feed the gas back into the side of the gasifier reactor before exiting at the burning. After these modifications, the gas produced, when ignited, burnt with a blue flame as that obtained during the burning of propane gas, which lasted for about 50 minutes.

The start-up time for the gasification of wood shavings and chunks was each about 10 minutes and it takes 30 minutes to operate steadily. A lot of smoke was produced during the start-up after which combustible gases were produced steadily.

$$
\text { Feedstock consumption rate }=\frac{\text { mass of feedstock fed into the gasifier }}{\text { total operation time of steady-state period }}
$$


Using wood shavings as feedstock produced combustible gases, but bridging was observed at the throat. This was caused by the char produced from the wood shavings which did not allow the produced gas to flow through the grate to the outlet. Bridging has been observed for fluffy or light weight biomass by [23] for gasification of groundnut shells, [24] for sawdust and [15] for wood shavings. In addition to the bridging problem, it was observed that there was no free flow of feedstock within the gasifier into the throated region. The possible hindrance to flow is the nature of the feedstock as observed also by [23]. Hence, the grate had to be shaken regularly using the provided grate shaker to allow free flow of gas and feedstock. Unlike the wood shavings, the wood chunks flowed freely and there were no bridging problems observed during its gasification. It was also observed that a lot of smoke and tar oil was produced initially when the gasifier is loaded with feedstock.

To stop the gasifier, the blower is switched-off then the top of the gasifier is closed to completely stop air supply.

\subsection{Biomass fuel consumption}

When the gasifier was run on wood chunks it consumed around $1.25 \mathrm{~kg} / \mathrm{hr}$ to give a stable flame for 50 minutes. On the other hand, when it was fed with wood shavings, fuel consumption was $2.1 \mathrm{~kg} / \mathrm{hr}$. This result compares favourably with [25], who achieved a stable flame for 91 minutes from $2.9 \mathrm{~kg} / \mathrm{hr}$ wood pellets and $3.1 \mathrm{~kg} / \mathrm{hr}$ wood chunks respectively, and [15], who achieved stable flame for 15 minutes per $\mathrm{kg}$ of wood shavings. Figures 6 and 7 show the produced syngas ignited at the burner. The residues from the gasification process are shown in the Figures 8 and 9.

\section{CONCLUSION}

A downdraft gasifier was designed, constructed and tested in the present study. The thermal power of 5 $\mathrm{kW}$ was targeted which led to an estimated biomass consumption rate of $1.511 \mathrm{~kg} / \mathrm{hr}$ and a throat diameter of $5.4 \mathrm{~cm}$. The constructed gasifier has a larger reactive zone than the gasifier designed with a throat diameter of $9 \mathrm{~cm}$. A syngas purification system, comprising a cyclone separator, an air cooler unit and a filter unit (containing wood shavings) was coupled to the gasifier to purify the produced syngas. Biomass consumption of $1.25 \mathrm{~kg}$ and $2.1 \mathrm{~kg}$ per hour were achieved during the gasification of wood chunks and wood shavings respectively. Syngas production, which is indicated by gas ignition at the burner, was observed during the gasification of both types of wood residues. Steady blue flames from the produced syngas indicates low percentage of tar. This indicates that the designed purification system was effective in removing particulate matters, moisture and tars from produced syngas. Hence, this signifies that the produced syngas can be safely utilized not only for cooking but also in internal combustion engines to generate electricity.
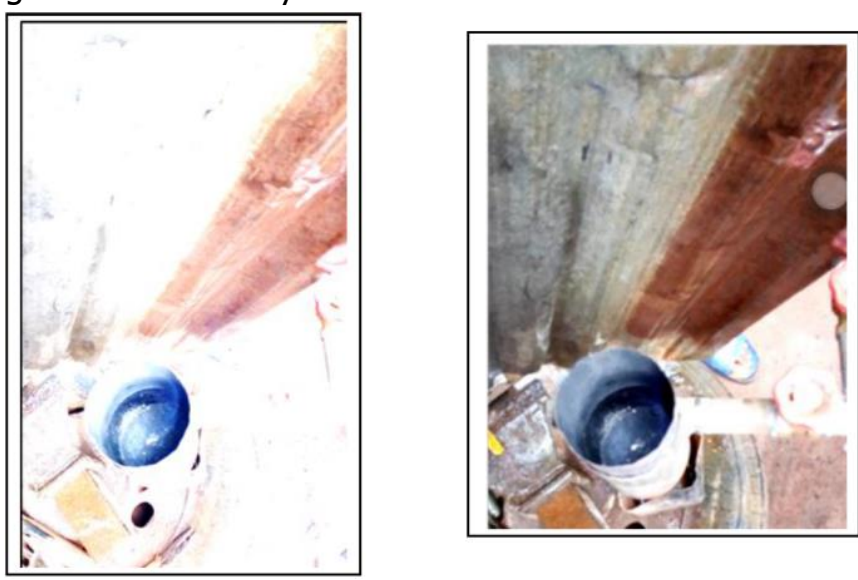

Figure 6: Produced syngas burning with stable blue

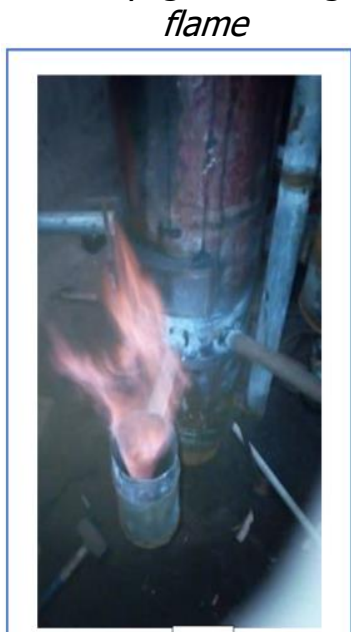

Figure 7: Produced syngas burning with yellowish-red flame

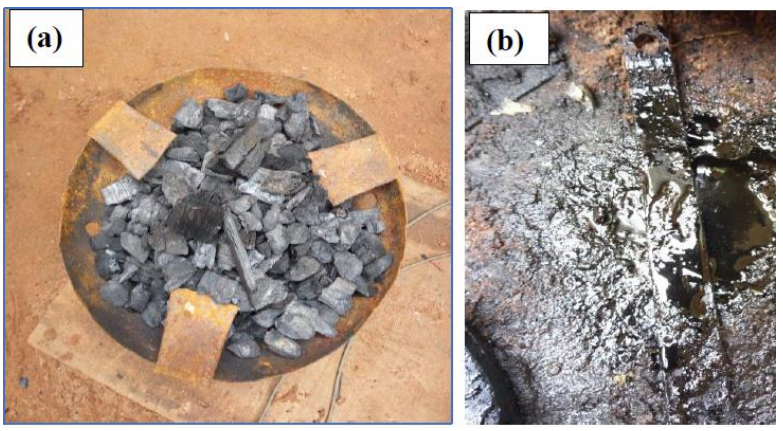

Figure 8: (a) char and (b) tar 

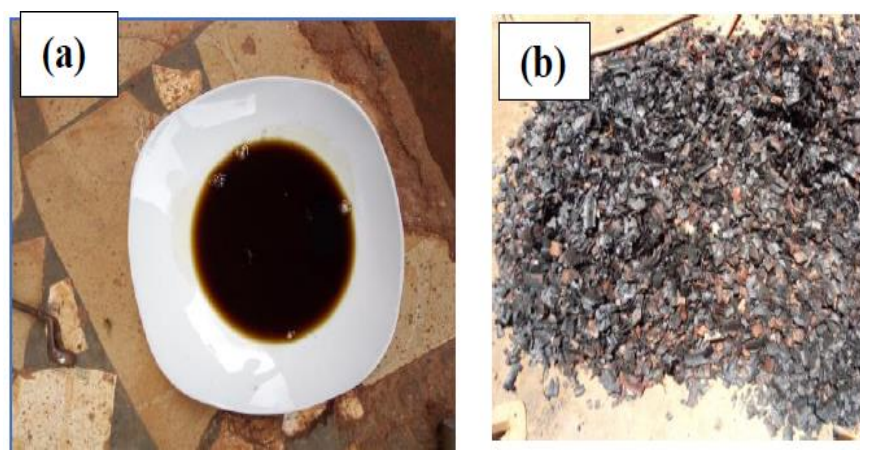

Figure 9: (a) water and (b) wood shavings from filter

\section{REFERENCES}

[1] A. Demirbas, "Combustion characteristics of different biomass fuels," Progress in Energy and Combustion Science, vol. 30, no. 2, pp. 219-230, 2004.

[2] P. N. Sheth and B. V. Babu, "Experimental studies on producer gas generation from wood waste in a downdraft biomass gasifier," Bioresource Technology, vol. 100, no. 12, pp. 3127-3133, 2009.

[3] T. A. Milne, and R. J. Evan, "Biomass gasification "tars"; their nature, formation and conversion," in, NREL, Golden, CO, USA, 1998.

[4] Y. Cao, Y. Wang, J. T. Riley, and W. P. Pan, "A novel biomass air gasification process for producing tar-free higher heating value fuel gas, "Fuel Processing Technology, vol. 87, no. 4, pp. 343-353, 2006.

[5] V. Christus, J. Singh, S. J. Sekhar, and K. Thyagarajan, "Performance studies on downdraft gasifier with biomass energy sources available in remote villages," Am. J. Appl. Sci., vol. 11, no. 4, pp. 611-622, 2014.

[6] E. Virmond, J. D. Rocha, R. F. P. M. Moreira, and $H$. J. Jose, "Valorization of agro- industrial solid residues and residues from biofuel production chains by thermochemical conversion: A review, citing Brazil as a case study," Brazillian Journal of Chemical Engineering, vol. 30, pp. 197-230, 2013.

[7] H. S. Mukunda, S. Dasappa, P. J. Paul, N. K. S. Rajan, and U. Shrinivasa, "Gasifiersand combustors for biomass - technology and field studies," Energy for Sustainable Development, vol. 1, no. 3, pp. 27-38, 1994.

[8] M. Barrio, M. Fossum, and J. E. Hustad, "A smallscale stratified downdraft gasifier coupled to a gas engine for combined heat and power production," in Progress in Thermochemical

Nigerian Journal of Technology,
Biomass Conversion, Ed. A.V. Bridgwater, Wiley-

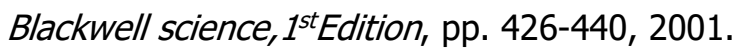

[9] S. Dasappa, P. J. Paul, H. S. Mukunda, N. K. S. Rajan, G. Sridhar, and H. V. Sridhar, "Biomass gasification technology- a route to meet energy needs," Current Science, vol. 87, pp. 908- 916, 2004.

[10] L. Liinanki, P. J. Svenningsson, and G. Thessen, "Gasification of agricultural residues in a downdraft gasifier," Presented at the $2^{\text {nd }}$ International Producer Gas Conference, Bangdung, Indonesia, 1985.

[11] C. R. Altafini, P.R. Wander, and R. M. Barreto, "Assessment of a small sawdust gasification unit," Biomass \& Bioenergy, 27: 467-476, 2004.

[12] DFID, "Bioenergy for sustainable energy access in Africa, a technology value chain prioritisation report," PO 7420, 2017.https://www.carbontrust.com/media/6762 48/bseaa-tvc-prioritisation-report.pdf Accessed October13, 2018.

[13] I. H. Gado, O. Sanogo, T. Daho, B. Issa and P. Josue, "Design, realization of a fixed bed downdraft gasifier and conduction of preliminary gasification tests with balanitesaegyptiaca hulls, rice husk and charcoal", African Journal of Environmental Science and Technology, vol. 13, no. 3, pp. 117-125.

[14] A. O. Akinola, and O. P. Fapetu, "Characteristics Study of Wood Wastes from Sawmills" British Journal of Applied Science \& Technology, vol. 6, no. 6, pp. 606-612, 2015.

[15] S. J. Ojolo, and J. I. Orisaleye, "Design and development of a laboratory scale biomass gasifier," Journal of Energy and Power Engineering, vol. 4, no. 8, pp. 16-23, 2010.

[16] I. M. Mobi, I. Ezeonuegbu, and I. U. Onyenanu, "Production of gasifier stove for use in Nigeria: an alternative energy awareness," International Journal of Engineering and Technical Research, vol. 1, no. 8, 2013.

[17] T. B. Reed, and A. Das, "Handbook of biomass downdraft gasifier engine systems," $1^{\text {st }} \mathrm{Ed}$, Solar Energy Research Institute, 1988.

[18] U. Henriksen, J. Ahrenfeldt, T. Jensen, B. Gobel, J. Bentzen, C. Hindsgaul, and L. Sorensen, "The design, construction and operation of a $75 \mathrm{~kW}$ two-stage gasifier," Energy, vol. 31, pp. 542-1553, 2006 
[19] J, Venselaar, "Design rules for downdraft wood gasifiers: A short review," IT Bandung, Indonesia, pp. 1-24, 1986.

[20] S. Sivakumar, K. Pitchandi, E. Natarajan, "Modelling and simulation of down draft wood gasifier," Journal of Applied Sciences, vol. 8, no. 1, pp. 271-279, 2008.

[21] S. Sivakumar, K. Pitchandi, E. Natarajan, "Design and analysis of downdraft gasifierusing computational fluid dynamics, Department of Mechanical Engineering, College of Engineering, Anna University, Guindy, India, 2006.

[22] M. Fodora, J. Gadua, J. Marecek, T. Vitex, and V.Kazimirova, "Design of laboratory cyclone separator for biogas purification," Acta Universitatis Agriculturae et Silviculturae
Mendelianae Brunensis, vol. 61, no. 3, pp. 631635, 2012.

[23] L. Kumararaja, "Development of gasifier suitable for non-woody bio-residues for electric power generation", Project Report, Department of Science, Technology and Environment, Govt. of Puducherry, Puducherry-605 014, 2009.

[24] I. Rudakova, "Use of biomass gasification for transport", Master's Thesis, Faculty of Technology, Lappeeranta University of Technology, Finland, 2009.

[25] M. A. Chawdhury and K. Mahkamov, "Development of a small downdraft biomass gasifier for developing countries", Journal of Scientific Research, vol. 3, no. 1, pp. 51-64, 2011. 